\title{
PERANCANGAN ALAT PENGGERAK ANTENA MENGGUNAKAN METODE KONTROL PROPORTIONAL, INTEGRAL, DERIVATIVE (PID) UNTUK MELACAK OBJEK BERGERAK
}

\author{
Bagus Bernadi Saputra*), Wahyudi, dan Sudjadi \\ Departemen Teknik Elektro, Universitas Diponegoro \\ Jl. Prof. Sudharto, SH, Kampus UNDIP Tembalang, Semarang 50275, Indonesia \\ ${ }^{*}$ E-mail: bagus.bernadi@gmail.com
}

\begin{abstract}
Abstrak
Base station atau Ground Control Station (GCS) umumnya menggunakan antena directional untuk dapat berkomunikasi dengan objek bergerak seperti roket dan Unmanned Aerial Vehicle (UAV). Antena directional memiliki jarak jangkau yang jauh, namun memiliki sudut pancar yang sempit. Untuk mengatasi kekurangan dari antena directional, diperlukan alat yang dapat menggerakkan antena ke arah objek bergerak secara nyata pada kisaran sudut azimut dan elevasi. Pada penelitian ini, dirancang alat penggerak antena menggunakan metode kontrol Proportional, Integral, dan Derivative (PID) untuk melacak objek bergerak berbasis Global Positioning System (GPS) dan sensor barometer. Dari hasil perancangan dengan menggunakan nilai parameter PID yang digunakan pada sudut elevasi $(\mathrm{Kp}=0,03, \mathrm{Ti}=150$, dan $\mathrm{Td}=0,22)$ menghasilkan plant yang mampu mencapai setpoint $\left(74^{\circ}\right)$ dalam waktu 2 detik. Parameter PID yang digunakan pada sudut azimut $(\mathrm{Kp}=3,5, \mathrm{Ti}=100$, dan $\mathrm{Td}=0,09)$ menghasilkan plant yang mampu mencapai setpoint $\left(180^{\circ}\right)$ dalam waktu 1,1 detik. Dari hasil pengujian, diketahui antena dapat mengikuti objek bergerak (drone) dengan waktu terlama 1 detik pada plant azimut dan 1,5 detik pada plant elevasi. Plant elevasi memiliki Mean Absolute Error (MAE) $=6,54^{\circ}$ dan plant azimut memiliki MAE $=8,04^{\circ}$.
\end{abstract}

Kata Kunci: alat penggerak antena, kontrol PID, pelacak objek bergerak, Ground Control Station, GPS

\begin{abstract}
Generally, base station or Ground Control Station (GCS) use directional type of antennas to comunicate with the moving object such as a rocket and an Unmanned Aerial Vehicle (UAV). Directional antenna has a long transmission range but narrow transmission angle. In order to overcome this shortcoming, a device that can move the antenna towards a moving object is needed. This research designs a device which can controll antenna motion on the azimuth and elevation axis. This device is using Proportional, Integral, dan Derivative (PID) control method to track moving object base on Global Positioning System (GPS) and barometer sensor. From the PID parameter that used at elevation angle $(\mathrm{Kp}=0.03, \mathrm{Ti}=150$, and $\mathrm{Td}=0.22)$, the plant can reach the setpoint $\left(74^{\circ}\right)$ within 2 second. From the PID parameter that used at azimuth angle $(\mathrm{Kp}=3.5, \mathrm{Ti}=100$, and $\mathrm{Td}=0.09)$, the plant can reach the setpoint $\left(180^{\circ}\right)$ within 1.1 second. Based on the test result, antenna can move to follow object (drone) with the longest time 1 second on the azimut plant and 1.5 second on the elevation plant. The Mean Absolute Error (MAE) at the azimut plant is $6.54^{\circ}$ and the MAE at the elevation plant is $8.04^{\circ}$.
\end{abstract}

Keywords: antenna motion controll, PID controll, moving object tracker, Ground Control Station, GPS

\section{Pendahuluan}

Pada wahana bergerak yang memiliki area jelajah luas seperti roket atau Unmanned Aerial Vehicle (UAV), dibutuhkan antena pada sisi objek dan pada stasiun bumi atau base station atau Ground Control Station (GCS) untuk dapat melakukan komunikasi. Antena yang digunakan GCS umumnya berjenis directional karena memiliki jarak jangkau yang lebih jauh dibanding antena omnidirectional dengan penggunaan daya yang sama [1]. Pada GCS, umumnya terdapat sistem yang dapat menggerakkan antena ke arah objek bergerak pada waktu-nyata di kisaran sudut azimut dan sudut elevasi, tujuannya adalah untuk mengatasi kekurangan dari antena directional yang memiliki sudut pancar yang sempit. Salah satu metode yang dapat digunakan untuk melacak objek bergerak adalah dengan bantuan Global Postioning System (GPS) receiver yang dipasang pada GCS dan juga objek bergerak sehingga diketahui koordinat, ketinggian terhadap permukaan laut, dan sudut diantara keduanya [2].

Penelitian dan pengembangan alat penggerak antena yang telah dilakukan antara lain sebagai penerima data video link dari sebuah UAV menggunakan 5 kanal antena monopulse 
[3], penelitian menggunakan metode kontrol seperti kontroler Proportional [2], kontroler ProportionalIntegral (PI) [4], kontroler Proportional, Integral, Derivative (PID) [5], [6], algoritma step-tracking dengan kontroler $\mathrm{H} \infty$ untuk desain tracking loop tertutup [7], hingga menggunakan Fuzzy-PD [8], [9]. Dari penelitian yang telah dilakukan, metode pelacakan yang banyak digunakan adalah Received Signal Strength Indicator (RSSI). Pada penelitian ini, dirancang alat penggerak antena menggunakan metode kontrol PID untuk melacak muatan objek bergerak berbasis GPS.

\section{Metode}

Perancangan sistem alat penggerak antena terdiri atas perancangan Graphical User Interface (GUI), antena Yagi-Uda 433MHz, muatan objek bergerak, dan alat penggerak antena.

\subsection{Perancangan Antena Yagi-Uda $433 \mathrm{MHz}$}

Perancangan antena Yagi-Uda $433 \mathrm{MHz}$ dilakukan menggunakan perangkat lunak CST Studio Suite hingga terpenuhi syarat VSWR $\leq 2$ dan return loss $\leq-10 \mathrm{~dB}$. Spesifikasi antena yang didapatkan dari hasil perancangan ditunjukkan pada Tabel 1, diketahui $\lambda=69,3 \mathrm{~cm}$. Penentuan rumus umum didapat melalui metode trial and error berdasarkan dari referensi [10], [11]. Kemudian antena dipabrikasi. Hasil pabrikasi antena dapat dilihat pada Gambar 2. Dari hasil pabrikasi, dilakukan pengujian dengan hasil VSWR $=1,078$, return loss $=-28,436 \mathrm{~dB}$, impedansi $=49,352 \Omega$, dan gain $=10,63 \mathrm{~dB}$. pola radiasi antena dapat dilihat pada Gambar 3. Dari hasil perhitungan link budget, didapatkan nilai link budget untuk jarak transmisi antena sejauh $1 \mathrm{~km}=63,46 \mathrm{dBm}$ (nilai minimal link budget $=15 \mathrm{dBm})$.

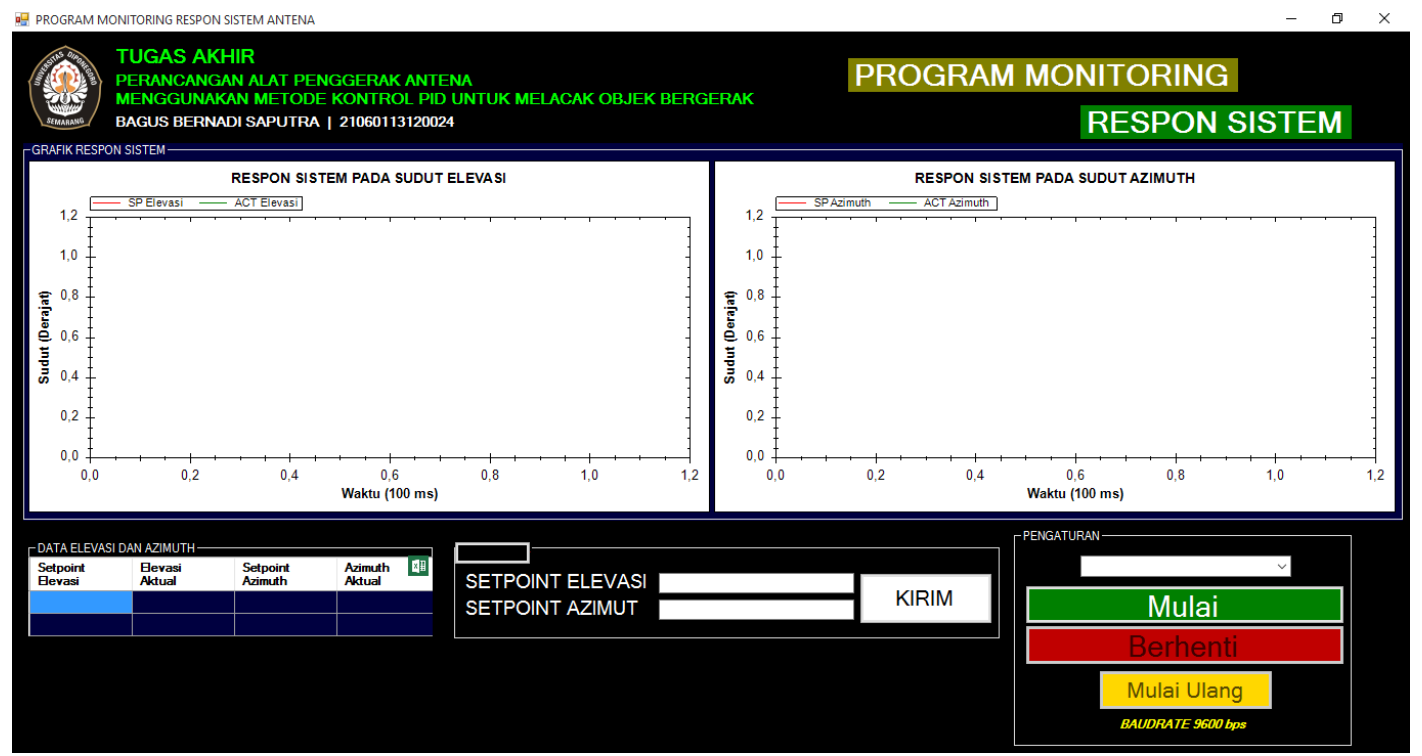

Gambar 1. GUI pembacaan respon sistem alat penggerak antena

\subsection{Perancangan GUI}

Pada penelitian ini, GUI digunakan untuk menampilkan 4 data (data aktual dan setpoint penggerak pada sumbu azimut dan elevasi) dalam bentuk grafik dan tabel, kemudian terdapat fitur save sehingga data dapat disimpan kedalam file Ms. Excel. GUI ini dirancang dengan menggunakan perangkat lunak Visual Studio C\#. Perancangan GUI bertujuan untuk mempermudah pembacaan respon sistem alat penggerak antena yakni dengan menampilkan 4 data (data aktual dan setpoint penggerak pada sumbu azimut dan elevasi) dalam bentuk grafik dan tabel, input setpoint elevasi dan azimut, serta terdapat fitur save sehingga data dapat disimpan kedalam file Ms. Excel. Tampilan GUI pembacaan respon sistem alat penggerak antena dapat dilihat pada Gambar 12.
Tabel 1. Spesifikasi antena Yagi-Uda 433MHz

\begin{tabular}{clcc}
\hline No & \multicolumn{1}{c}{ Elemen } & Rumus umum & Hasil \\
\hline 1 & Panjang reflector & $0,475 \lambda$ & $32,917 \mathrm{~cm}$ \\
2 & Panjang driven & $0,425 \lambda$ & $29,452 \mathrm{~cm}$ \\
3 & Panjang director 1 & $0,375 \lambda$ & $25,987 \mathrm{~cm}$ \\
4 & Panjang director 2 & $0,325 \lambda$ & $22,522 \mathrm{~cm}$ \\
5 & Panjang director 3 & $0,275 \lambda$ & $19,057 \mathrm{~cm}$ \\
6 & Jarak antar elemen & $0,2 \lambda$ & $13,86 \mathrm{~cm}$ \\
7 & Diameter elemen & $10 \mathrm{~mm}$ & $1 \mathrm{~cm}$ \\
\hline
\end{tabular}

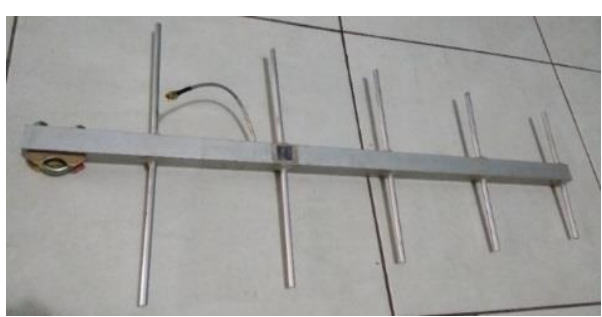

Gambar 2. Hasil pabrikasi Antena Yagi - Uda 433MHz 

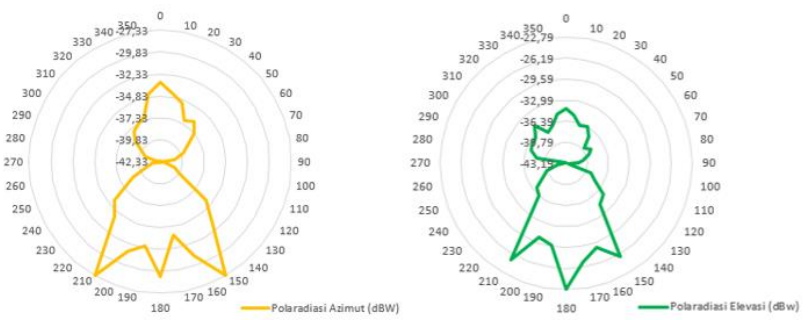

Gambar 3. Grafik hasil pengujian polaradiasi antena

\subsection{Perancangan Muatan Objek Bergerak}

Cara kerja dari perangkat ini adalah data koordinat dari GPS Receiver yang masih berformat NMEA diolah oleh mikrokontroler menjadi representasi koordinat latitude dan longitude muatan objek bergerak. Data ketinggian dari sensor BMP-280 dikirimkan ke mikrokontroler untuk dijadikan representasi ketinggian muatan objek bergerak. Selanjutnya, data ketinggian, latitude, dan longitude muatan objek bergerak dikirim oleh mikrokontroler ke alat penggerak antena melalui modul radio telemetri 3DR $433 \mathrm{MHz}$ menggunakan format yang dapat dimengerti oleh alat penggerak antena. Blok diagram perancangan elektronika dan hasil perancangan muatan objek bergerak dapat dilihat pada Gambar 4 dan Gambar 5.

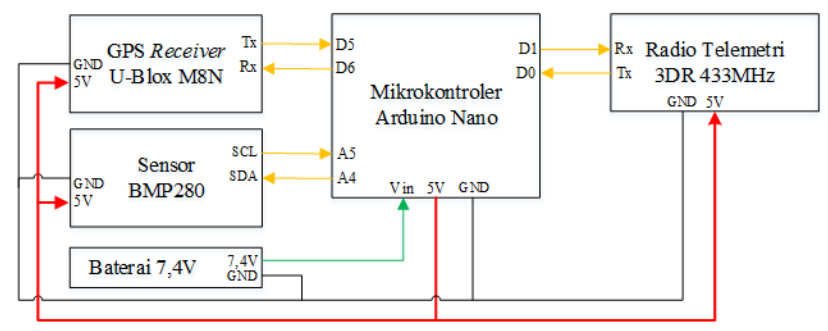

Gambar 4. Blok diagram perancangan elektronika muatan objek bergerak

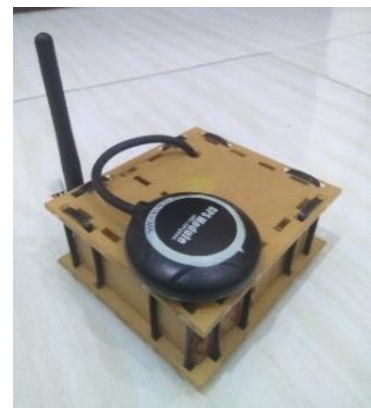

Gambar 5. Hasil rancangan muatan objek bergerak

\subsection{Perancangan Alat Penggerak Antena}

Cara kerja dari alat penggerak antena berbasis GPS ini adalah, modul radio telemetri 3DR $433 \mathrm{MHz}$ mengirimkan data latitude, longitude, dan ketinggian yang diterima dari muatan objek bergerak ke mikrokontroler ATMega328. Data latitude, longitude, dan ketinggian antena diinisialisasikan secara manual ke dalam senarai program. Data latitude, longitude, serta ketinggian muatan objek bergerak dan antena dimasukkan kedalam persamaan bearing, haversine, dan trigonometri sehingga menghasilkan nilai setpoint sudut azimut, dan setpoint sudut elevasi. Setpoint sudut azimut kemudian dibandingkan dengan sudut hadap antena (sudut aktual) yang direpresentasikan oleh sudut kompas pada sensor HMC5883L sehingga diketahui nilai error azimut. Setpoint sudut elevasi dibandingkan dengan sudut elevasi antena yang direpresentasikan oleh sudut pitch pada sensor MPU-6050 sehingga diketahui nilai error elevasi. Error elevasi dan error azimut kemudian diolah menggunakan metode kontrol PID yang selanjutnya dijadikan nilai PWM pada masing-masing servo elevasi dan servo azimut. Blok diagram perancangan elektronika dan hasil perancangan alat penggerak antena dapat dilihat pada Gambar 6 dan Gambar 7.

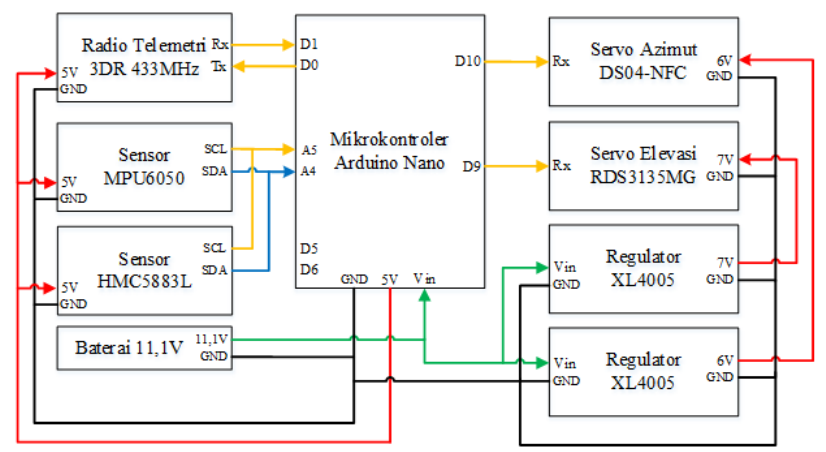

Gambar 6. Blok diagram perancangan elektronika alat penggerak antena

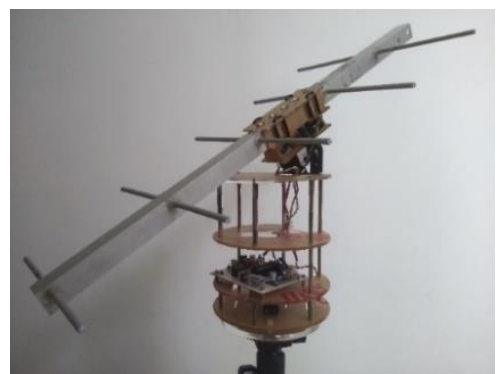

Gambar 7. Hasil perancangan alat penggerak antena

\subsection{Perancangan Kontrol PID}

Dalam penelitian ini, digunakan dua kontrol PID yang masing-masing berfungsi untuk mengontrol motor servo elevasi dan azimut. Masing-masing plant ini bekerja dengan error elevasi dan error azimut sebagai input-nya. Diagram kontrol PID pengendalian gerak antena pada sumbu elevasi dan azimut masing-masing dapat dilihat pada Gambar 8 dan Gambar 9. Kontrol PID dimasukkan ke dalam mikrokontroler menggunakan senarai program. Nilai periode sampling (Ts) ditentukan berdasarkan dari interval proses looping pada mikrokontroler yakni $50 \mathrm{~ms}$ 
atau 0,05 detik. Nilai $\mathrm{Kp}, \mathrm{Ki}$, dan $\mathrm{Kd}$ diperoleh melalui tuning trial and error [12]. Setpoint sudut elevasi didapat dari perhitungan sudut elevasi antara objek bergerak dan antena (sebelumnya dihitung selisih ketinggian dan jarak keduanya). Setpoint azimut didapat dari perhitungan sudut bearing antara objek dan antena.

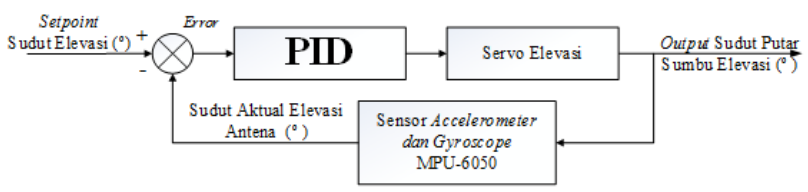

Gambar 8. Diagram kontrol servo elevasi

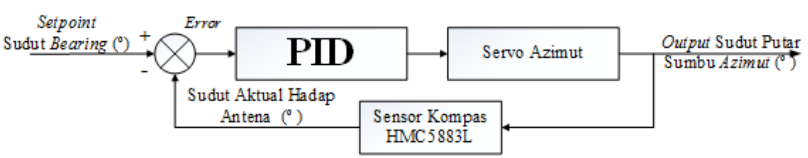

Gambar 9. Diagram kontrol servo azimut

\subsubsection{Perancangan kontrol PID pada plant elevasi}

Perancangan kontrol PID pada sumbu elevasi alat penggerak antena dilakukan untuk menentukan nilai $\mathrm{Kp}$, $\mathrm{Ti}$, dan Td yang menghasilkan respon sistem yang memiliki rise time cepat, tanpa overshoot, dan error steady state kecil. Respon sistem yang diuji adalah respon saat antena berada di sudut $0^{\circ}$ dengan setpoint $74^{\circ}$.

Tuning parameter PID dilakukan secara bertahap dari penentuan nilai $\mathrm{Kp}$ (didapat nilai $\mathrm{Kp}=0,03$ dengan hasil plant memiliki rise time $=1600 \mathrm{~ms}$, overshoot $4^{\circ}$, error steady state $=1^{\circ}$, dan settling time $=3000 \mathrm{~ms}$ ), kemudian ditentukan nilai $\mathrm{Td}$ (didapat nilai $\mathrm{Td}=0,22$ dengan hasil plant memiliki risetime dan settling time $=2300 \mathrm{~ms}$, tidak memiliki overshoot, dan error steady state $=1^{\circ}$ ), kemudian ditentukan nilai $\mathrm{Ti}$ (didapat nilai $\mathrm{Ti}=150$ dengan hasil plant memiliki rise time dan settling time $=2000 \mathrm{~ms}$, tidak memiliki overshoot, dan error steady state $=0^{\circ}$ ). Dari hasil tuning parameter PID, ditentukan nilai parameter PID untuk plant elevasi alat penggerak antena adalah dengan nilai $\mathrm{Kp}=0,03, \mathrm{Ti}=150$, dan $\mathrm{Td}=0,22$ dengan hasil sistem yang mampu mencapai setpoint $74^{\circ}$ dalam waktu 2000ms tanpa overshoot. Grafik respon plant elevasi dengan nilai parameter $\mathrm{Kp}=0,03, \mathrm{Ki}=0$, dan $\mathrm{Kd}=0$ dapat dilihat pada Gambar 10. Grafik respon plant elevasi dengan nilai parameter $\mathrm{Kp}=0,03, \mathrm{Ti}=150$, dan $\mathrm{Td}=0,22$ dapat dilihat pada Gambar 11.

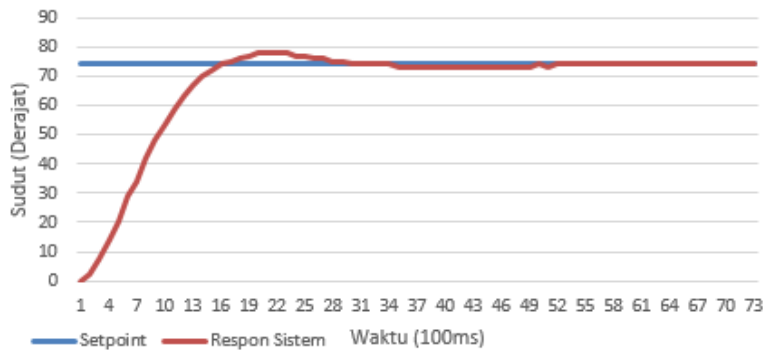

Gambar 10. Respon sistem elevasi hanya dengan $K p=0,03$, $\mathrm{Kd}=\mathbf{0}, \operatorname{dan} \mathrm{Ki}=\mathbf{0}$

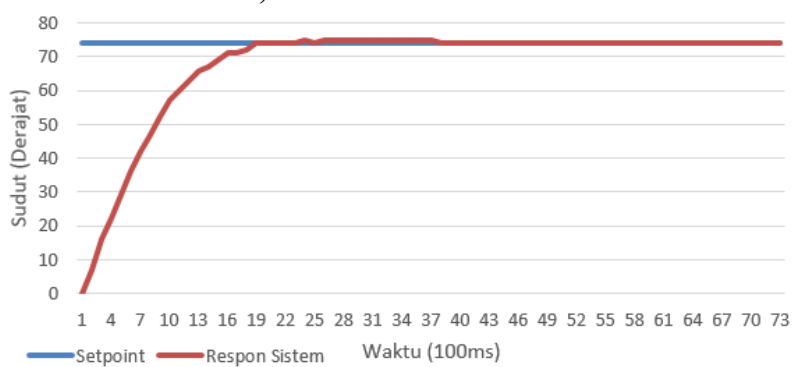

Gambar 11. Respon sistem elevasi dengan $\mathrm{Kp}=0,03, \mathrm{Td}=$ 0,22, dan $\mathrm{Ti}=150$

\subsubsection{Perancangan kontrol PID pada plant azimut}

Perancangan kontrol PID pada sumbu azimut alat penggerak antena dilakukan untuk menentukan nilai $\mathrm{Kp}$, $\mathrm{Ti}$, dan $\mathrm{Td}$ yang menghasilkan respon sistem yang memiliki rise time cepat, minim overshoot, dan error steady state $=0$. Respon sistem yang diuji adalah respon saat antena berada di sudut $0^{\circ}$ dengan setpoint $180^{\circ}$.

Tuning parameter PID dilakukan secara bertahap dari penentuan nilai $\mathrm{Kp}$ (didapat nilai $\mathrm{Kp}=3,5$ dengan hasil plant memiliki rise time $=1000 \mathrm{~ms}$, overshoot $5^{\circ}$, error steady state $=2^{\circ}$, dan settling time $=1700 \mathrm{~ms}$ ), kemudian ditentukan nilai $\mathrm{Td}$ (didapat nilai $\mathrm{Td}=0,09$ dengan hasil plant memiliki risetime $=1100 \mathrm{~ms}$, settling time $=1500 \mathrm{~ms}$, tidak memiliki overshoot, dan error steady state $=3^{\circ}$ ), kemudian ditentukan nilai $\mathrm{Ti}$ (didapat nilai $\mathrm{Ti}=100$ dengan hasil plant memiliki rise time dan settling time $=$ $1100 \mathrm{~ms}$, tidak memiliki overshoot, dan error steady state $=1^{\circ}$ ). Dari hasil tuning parameter PID, ditentukan nilai parameter PID untuk plant azimut alat penggerak antena adalah dengan nilai $\mathrm{Kp}=3,5, \mathrm{Ti}=100$, dan $\mathrm{Td}=0,09$ dengan hasil sistem yang mampu mencapai setpoint $180^{\circ}$ dalam waktu $1100 \mathrm{~ms}$ tanpa overshoot. Grafik respon plant elevasi dengan nilai parameter $\mathrm{Kp}=3,5, \mathrm{Ki}=0$, dan $\mathrm{Kd}=$ 0 dapat dilihat pada Gambar 12. Grafik respon plant elevasi dengan nilai parameter $\mathrm{Kp}=3,5, \mathrm{Ti}=100$, dan $\mathrm{Td}=0,09$ dapat dilihat pada Gambar 13. 


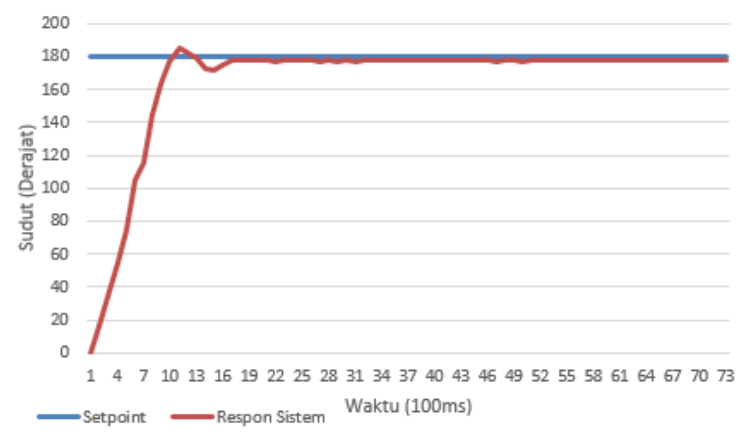

Gambar 12. Respon sistem elevasi dengan $\mathrm{Kp}=3,5, \mathrm{Ki}=\mathbf{0}$, dan $\mathrm{Kd}=0$

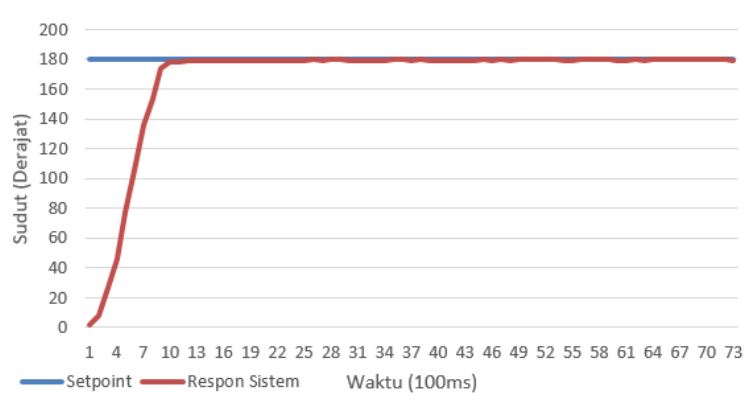

Gambar 13. Respon sistem elevasi dengan $\mathrm{Kp}=3,5, \mathrm{Ti}=100$, dan $\mathrm{Td}=0,09$

\section{Hasil dan Analisis}

Hasil penelitian ini diperoleh melalui serangkaian pengujian seperti pengujian sensor-sensor, pengujian alat penggerak antena terhadap setpoint yang berubah-ubah, pengujian alat penggerak antena terhadap jarak yang ditentukan, dan pengujian antena terhadap jarak yang tidak ditentukan.

\subsection{Pengujian Sensor}

Pengujian ini bertujuan untuk mengetahui nilai akurasi tiap-tiap sensor yang digunakan pada sistem alat penggerak antena.

\subsubsection{Pengujian sensor MPU-6050}

Pengujian sensor accelerometer dan gyroscope MPU-6050 dilakukan dalam rentang sudut $0^{\circ}$ hingga $74^{\circ}$ (batas sudut kerja alat penggerak antena) dengan pengambilan data tiap $5^{\circ}$. Nilai error sensor didapat dengan membandingkan nilai sudut keluaran sensor MPU-6050 dengan nilai sudut dari pembacaan busur. Dari hasil pengujian, diketahui bahwa sensor MPU-6050 yang digunakan untuk membaca arah hadap antena di sudut elevasi memiliki error terbesar $=1^{\circ}$.

\subsubsection{Pengujian sensor HMC5883L}

Pengujian sensor magnetometer HMC5883L dilakukan dalam rentang sudut $0^{\circ}$ hingga $180^{\circ}$ (batas sudut kerja alat penggerak antena) dengan pengambilan data tiap $10^{\circ}$. Nilai error sensor didapat dengan membandingkan nilai sudut keluaran sensor HMC5883L dengan nilai sudut dari pembacaan busur. Dari hasil pengujian, diketahui bahwa sensor HMC5883L yang digunakan untuk membaca arah hadap antena di sumbu azimut memiliki error rata-rata $=$ $8^{\circ}$ dengan error terbesar $=16^{\circ}$

\subsubsection{Pengujian sensor BMP280 dan GPS receiver U- Blox M8N}

Pengujian sensor barometric pressure BMP280 dan GPS receiver $\mathrm{U}-\mathrm{Blox} \mathrm{M} 8 \mathrm{~N}$ dilakukan secara bersamaan pada kondisi diam dan diletakkan pada sebuah batu penanda koordinat suatu lokasi (benchmark) seperti ditunjukkan pada Gambar 14. Nilai error sensor BMP280 didapatkan dengan membandingkan nilai ketinggian keluaran sensor BMP280 dengan nilai ketinggian pada benchmark yang telah diketahui nilainya. Nilai error pengujian GPS receiver didapatkan dengan membandingkan koordinat output GPS receiver dengan koordinat posisi benchmark yang telah diketahui nilainya. Pengambilan data dilakukan selama 10 detik (sebagai referensi bahwa muatan objek bergerak tidak diam dalam waktu lama) dengan interval pengiriman data $100 \mathrm{~ms}$. Pengujian dilakukan sebanyak 3 kali pada benchmark yang berbeda-beda. Dari hasil pengujian, diketahui sensor BMP280 memiliki error maksimal $=39 \mathrm{~m}$ dan GPS receiver memiliki error maksimal $=10 \mathrm{~m}$.

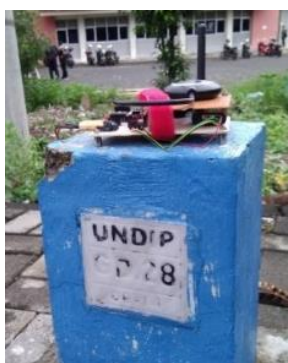

Gambar 14. Pengujian BMP280 dan GPS receiver pada benchmark

\subsection{Pengujian Alat Penggerak Antena \\ 3.2.1. Pengujian alat penggerak antena terhadap setpoint yang berubah-ubah}

Pengujian ini dilakukan untuk mengetahui respon alat penggerak antena pada saat diberikan setpoint yang berubah-ubah. nilai setpoint di-input-kan melalui GUI. Pengujian pada sudut elevasi dilakukan pada rentang $0^{\circ}$ sampai $74^{\circ}$. Pengujian dilakukan pada perubahan setpoint $0^{\circ}, 10^{\circ}, 20^{\circ}, 30^{\circ}, 40^{\circ}, 50^{\circ}, 60^{\circ}, 70^{\circ}$, dan $74^{\circ}$ dengan perubahan setpoint diturunkan dan dinaikkan. Pengujian pada sudut azimut dilakukan pada rentang $0^{\circ}$ sampai $360^{\circ}$. Pengujian dilakukan pada perubahan setpoint dengan kelipatan 30 dari $0^{\circ}$ sampai $360^{\circ}$ dengan perubahan setpoint diturunkan dan dinaikkan. Pengujian plant elevasi 
dapat dilihat pada Gambar 15 dan Gambar 16. Pengujian plant azimut dapat dilihat pada Gambar 17 dan Gambar 18.

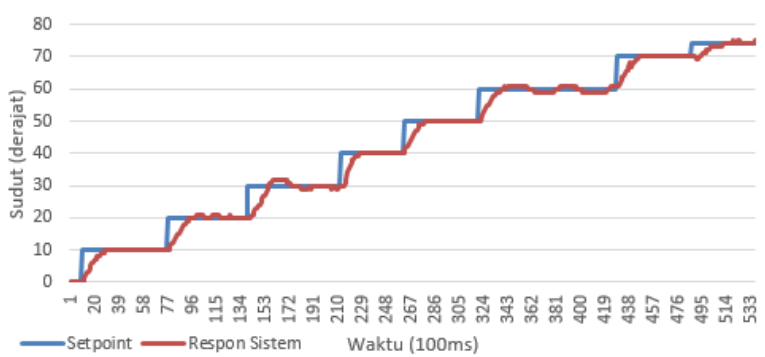

Gambar 15. Respon plant elevasi dengan setpoint berubah naik

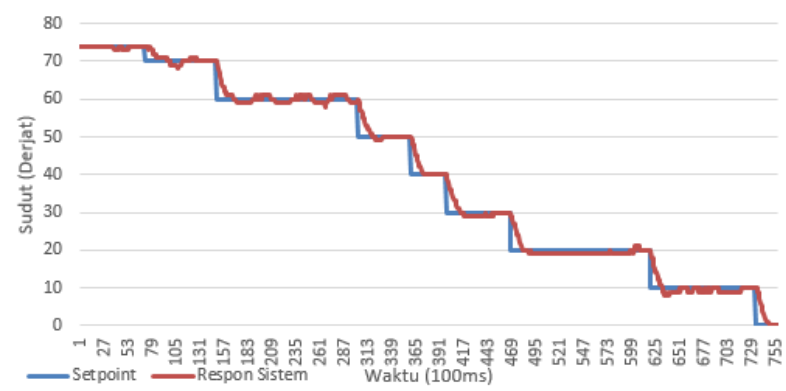

Gambar 16. Respon plant elevasi dengan setpoint berubah turun

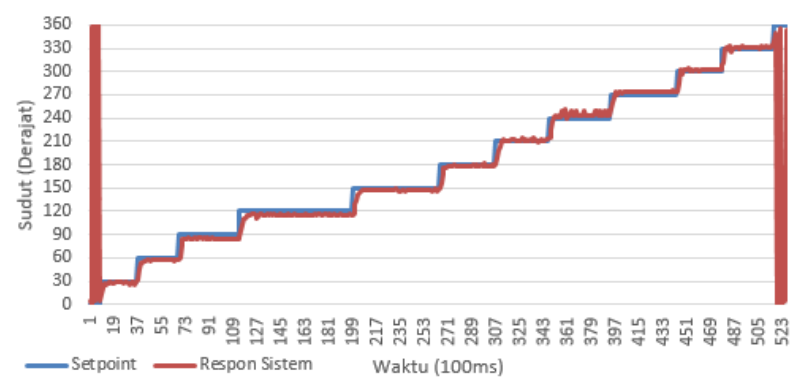

Gambar 17. Respon plant azimut dengan setpoint berubah naik

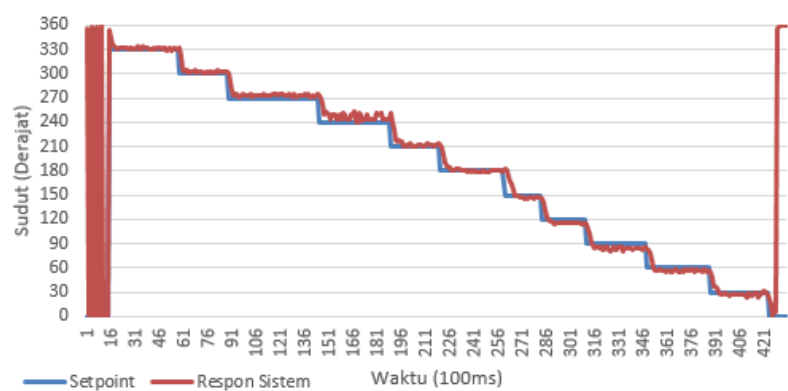

Gambar 18. Respon plant azimut dengan setpoint berubah turun

Dari hasil pengujian diatas, terdapat waktu yang berbedabeda untuk plant elevasi mencapai tiap setpoint. Hal ini dikarenakan terdapat gaya gravitasi yang mengakibatkan beban antena lebih besar atau lebih kecil untuk digerakkan servo (tergantung dari nilai setpoint). Pengaruh gaya gravitasi juga dapat dilihat pada perbedaan risetime yang cenderung lebih cepat pada saat pengujian setpoint berubah turun. Dari pengujian plant azimut, dapat dilihat bahwa terdapat karakteristik yang sama pada saat setpoint berubah turun dengan setpoint berubah naik. Diketahui pada saat setpoint $=180^{\circ}$, error steady state $=1$, namun pada setpoint $>180^{\circ}$ respon sistem cenderung berada diatas setpoint dan pada setpoint $<180^{\circ}$ respon sistem cenderung berada dibawah setpoint. Hal ini dikarenakan perancangan parameter PID dilakukan pada setpoint $180^{\circ}$, sehingga respon sistem terbaik hanya pada saat setpoint $=180^{\circ}$. Perbedaan risetime pada kedua pengujian ini (setpoint berubah naik dan berubah turun) sebesar 100ms hingga 400ms dikarenakan adanya perbedaan kecepatan gerak servo pada saat setpoint berubah turun (servo bergerak counter-clockwise) dan setpoint berubah naik (servo bergerak clockwise).

\subsubsection{Pengujian alat penggerak antena terhadap objek bergerak dengan jarak yang ditentukan}

Pengujian ini dilakukan untuk mengetahui respon alat penggerak antena terhadap gerak muatan objek yang telah ditentukan jaraknya (30m). Pengujian ini dilakukan di Lapangan Sepak Bola Undip, Semarang. Dari hasil pengujian, diketahui bahwa GPS receiver memiliki error penunjukkan lokasi objek hingga $18 \mathrm{~m}$. Hal ini dikarenakan berbagai macam faktor seperti kondisi cuaca, geometri satelit, metode penentuan posisi, ataupun jumlah satelit yang diterima [13]. Dari besarnya nilai error GPS ini dapat disimpulkan bahwa GPS tidak menunjukkan lokasi objek yang sebenarnya. Perbandingan jarak perhitungan objek dan jarak sebenarnya objek dapat dilihat pada Gambar 19.

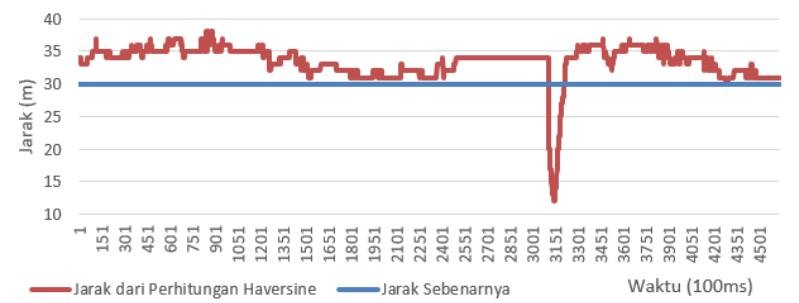

Gambar 19. Perbandingan jarak GPS dengan jarak sebenarnya.

\subsubsection{Pengujian alat penggerak antena terhadap objek bergerak dengan jarak yang tidak ditentukan}

Pengujian ini dilakukan untuk mengetahui respon alat penggerak antena terhadap objek bergerak (drone). Pada pengujian antena terhadap muatan objek yang bergerak melingkar di sumbu azimut dari sudut $360^{\circ}$ ke $0^{\circ}$. Dapat dilihat pada Gambar 20, plant mampu mencapai setpoint dalam waktu rata-rata $500 \mathrm{~ms}$ dan memiliki Mean Absolute Error $(\mathrm{MAE})=9,31^{\circ}$. Pada perubahan setpoint terbesar $=$ 
$57^{\circ}\left(180^{\circ}\right.$ ke $\left.123^{\circ}\right)$, plant membutuhkan waktu $600 \mathrm{~ms}$ untuk mencapai setpoint.

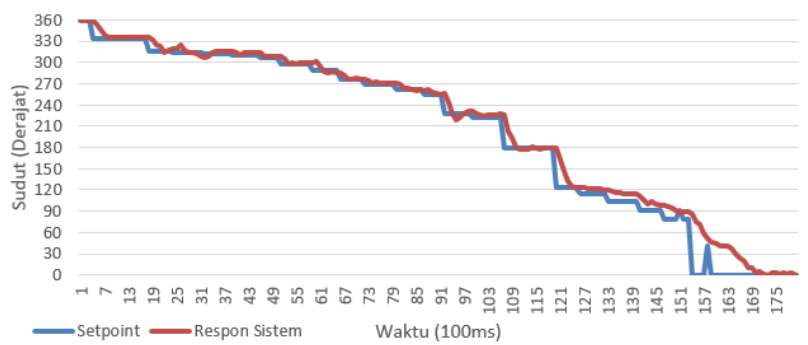

Gambar 20. Respon plant azimut pada objek bergerak melingkar

Pada pengujian antena terhadap muatan objek bergerak melingkar di sumbu elevasi dari sudut $17^{\circ}$ ke $88^{\circ}$. Dapat dilihat pada Gambar 21, plant mampu mencapai setpoint dalam waktu 500ms hingga $1500 \mathrm{~ms}$ dengan MAE $=6,47^{\circ}$. Pada waktu ke $17300 \mathrm{~ms}$ plant tidak mengikuti setpoint dikarenakan batasan sudut kerja antena yang hanya dapat memproses setpoint $\leq 74^{\circ}$ ( setpoint objek $=88^{\circ}$ ) sehingga plant tidak bergerak dari posisi setpoint terakhir. Dikarenakan perubahan setpoint yang berubah-ubah dalam waktu cepat dengan perubahan setpoint yang kecil sehingga plant tidak dapat bekerja dengan baik.

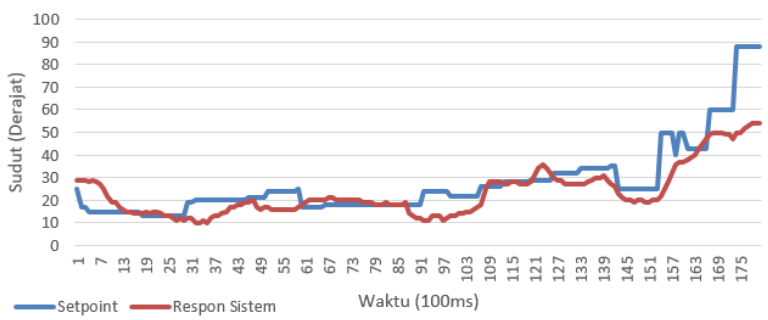

Gambar 21. Respon plant elevasi pada objek bergerak melingkar

Pada pengujian antena terhadap muatan objek bergerak horizontal di sumbu azimut dari sudut $180^{\circ}$ ke $72^{\circ}$ kemudian ke $171^{\circ}$ (bergerak bolak-balik). Dapat dilihat pada Gambar 22, plant mampu mencapai setpoint dalam waktu rata-rata $500 \mathrm{~ms}$ dengan $\mathrm{MAE}=4,62^{\circ}$.

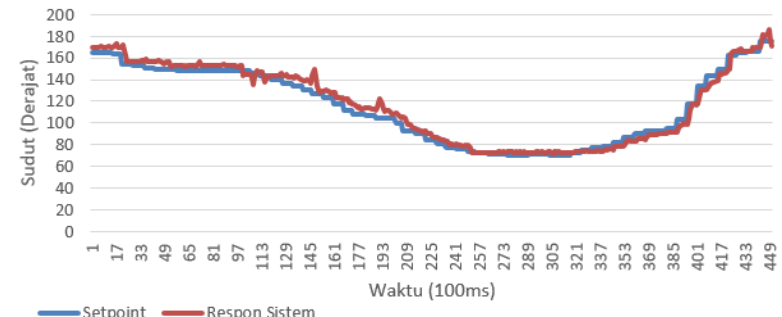

Gambar 22. Respon plant azimut pada objek bergerak horizontal
Pada pengujian antena terhadap muatan objek bergerak horizontal di sumbu elevasi bergerak fluktuatif dari sudut $80^{\circ}$ berakhir di sudut $21^{\circ}$. Dapat dilihat respon plant elevasi pada Gambar 23, plant mampu mencapai setpoint dalam waktu 500ms hingga $1500 \mathrm{~ms}$ dan $\mathrm{MAE}=2,04^{\circ}$.

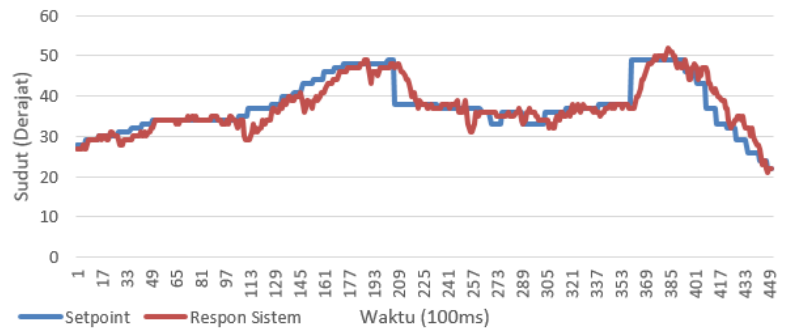

Gambar 23. Respon plant elevasi pada objek bergerak horizontal

Pada pengujian antena terhadap muatan objek bergerak melintasi alat penggerak antena, dapat dilihat pada Gambar 24 objek bergerak berputar dari sudut $346^{\circ}-39^{\circ}-76^{\circ}-360^{\circ}$ kemudian ke $282^{\circ}$. Pada pengujian ini, plant azimut mampu mencapai setpoint dalam waktu $500 \mathrm{~ms}$ hingga $1000 \mathrm{~ms}$ dan $\mathrm{MAE}=10,21^{\circ}$.

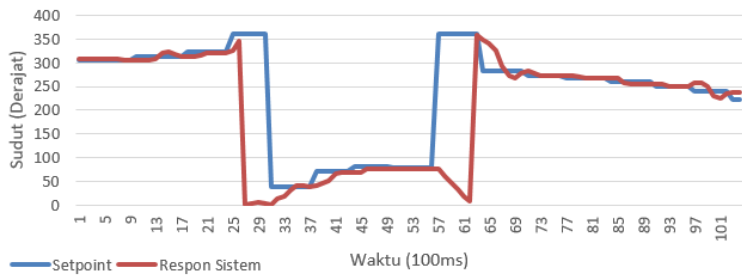

Gambar 24. Respon plant azimut pada objek bergerak melintas

Pada pengujian antena terhadap muatan objek bergerak melintasi alat penggerak antena, dapat dilihat pada Gambar 25 objek bergerak dari sudut $21^{\circ}$, naik ke $57^{\circ}$, kemudian turun kembali setelah muatan objek bergerak menjauh dari antena. Pada pengujian ini, plant mampu mencapai setpoint dalam waktu $1000 \mathrm{~ms}$ dan $\mathrm{MAE}=9,91^{\circ}$. Pada waktu ke 57 terlihat bahwa sistem tidak mencapai setpoint ( setpoint $=80$, aktual $=57)$. Hal ini dikarenakan batasan sudut kerja antena yang hanya memproses setpoint $\leq 74^{\circ}$.

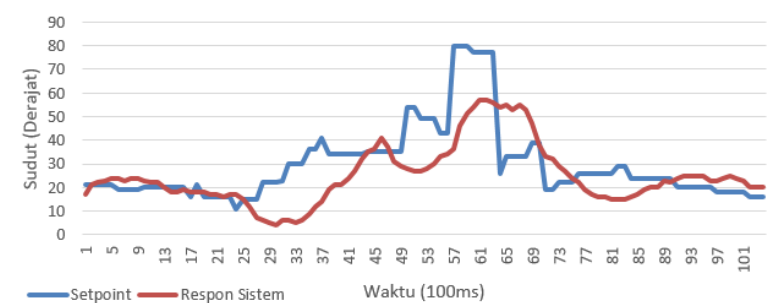

Gambar 25. Respon plant elevasi pada objek bergerak melintas 
Dari 6 data hasil pengujian diatas dapat disimpulkan bahwa, plant azimut mampu mencapai setpoint dalam waktu $500 \mathrm{~ms}$ sampai $1000 \mathrm{~ms}$ dan plant elevasi mampu mencapai setpoint dalam waktu 500ms sampai $1500 \mathrm{~ms}$. Masing-masing plant memiliki MAE $=8,04^{\circ}$ pada plant azimut dan $6,14^{\circ}$ pada plant elevasi. Dari pengujian diatas, dapat dibuat grafik gabungan untuk mengetahui respon kedua plant pada waktu yang sama. Gambar 26 adalah gambar gabungan dari plant azimut dan elevasi pada saat objek bergerak secara horizontal. Dari Gambar tersebut dapat dilihat bahwa respon sistem dapat mengikuti setpoint. Terdapat error (respon sistem tidak sesuai dengan setpoint) dikarenakan perbedaan waktu perubahan setpoint dan waktu respon pada masing-masing plant.

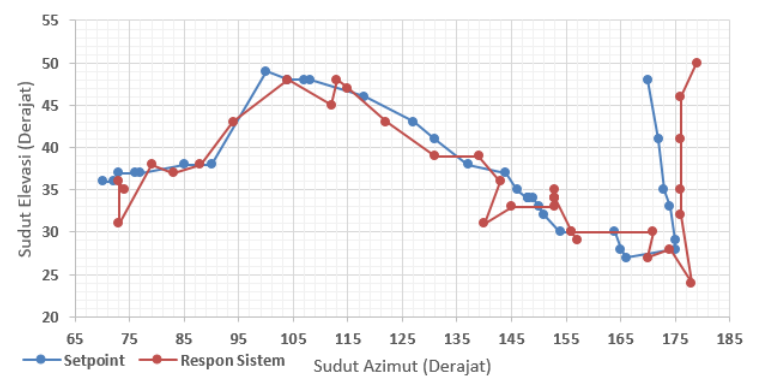

Gambar 26. Grafik gabungan respon sistem alat penggerak antena (azimut dan elevasi)

\section{Kesimpulan}

Telah berhasil dirancang alat pengendali gerak antena yang dapat mengikuti objek bergerak (drone) dengan waktu terlama $1000 \mathrm{~ms}$ pada plant azimut dan $1500 \mathrm{~ms}$ pada plant elevasi. MAE alat penggerak antena dalam mengikuti objek adalah $6,54^{\circ}$ pada plant elevasi dan $8,04^{\circ}$ pada plant azimut. Terdapat kesalahan arah hadap antena pada sudut elevasi dan azimut terhadap objek sebenarnya di lapangan dikarenakan sensor-sensor penyusun alat penggerak antena dan objek seperti HMC5883L, BMP280, dan GPS U-Blox M8N yang tidak presisi dalam merepresentasikan posisi objek dan antena. Respon sistem Alat penggerak antena ini tidak memiliki overshoot dengan settling time yang maksimal untuk design mekanik yang digunakan (mampu mencapai $74^{\circ}$ dalam waktu 2 detik pada plant elevasi dan mencapai $180^{\circ}$ dalam waktu 1,1 detik pada plant azimut).

\section{Referensi}

[1] Y. Guo and S. D. Prior, "Development of active gimbal system for directional antenna on a small Remotely Piloted Aircraft ( RPA ), " no. Figure 3.

[2] E. R. Juma, U. Sunarya, F. T. Elektro, and U. Telkom, "IMPLEMENTASI DAN ANALISIS KINERJA SISTEM AUTOMATIC TRACKING CONTROL POLARISASI ANTENA PENERIMA FREKUENSI 433 MHz BERBASIS GPS."

[3] S. Jenvey, J. Gustafsson, and F. Henriksson, "A PORTABLE MONOPULSE TRACKING ANTENNA FOR UAV Monash UAVs," in 22nd International Unmanned Air Vehicle System Conference.

[4] M. Kim, J. Kim, and O. Yang, "Precise attitude control system design for the tracking of parabolic satellite antenna," Int. J. Smart Home, vol. 7, no. 5, pp. 275-290, 2013.

[5] Y. Yalçin and S. Kurtulan, "A rooftop antenna tracking system: Design, simulation, and implementation," IEEE Antennas Propag. Mag., vol. 51, no. 2, pp. 214-224, 2009.

[6] M. B. Nugraha and R. Sumiharto, "Penerapan Sistem Kendali PID pada Antena Pendeteksi Koordinat Posisi UAV," IJEIS, vol. 5, no. 2, pp. 187-198, 2015.

[7] C.-H. Cho, S.-H. Lee, T.-Y. Kwon, and C. Lee, "Antenna Control System using Step Tracking Algorithm with $\mathrm{H} \infty$ Controller," Int. J. Control. Autom. Syst., vol. 1, no. 1, pp. 83-92, 2003.

[8] J. M. Lin and P. K. Chang, "Intelligent PD-type fuzzy controller design for mobile satellite antenna tracking system with parameter variations effect," IEEE SSCI 2011 - Symp. Ser. Comput. Intell. - CICA 2011 - 2011 IEEE Symp. Comput. Intell. Control Autom., vol. 1, pp. $1-5,2011$.

[9] P. K. Chang and J. M. Lin, "Mobile satellite antenna tracking system design with intelligent controller," WSEAS Trans. Syst. Control, vol. 3, no. 5, pp. 435-446, 2008.

[10] S. D. Murali et al., "Size Reduction of Yagi-Uda Antenna by Altering the Diameter and Spacing between the Elements," Int. J. Appl. Eng. Res., vol. 9, no. 22, pp. 12011-12022, 2014

[11] C. P. Frekuensi, S. Asyura, and A. H. Rambe, "Rancang Bangun Antena Yagi-Uda," pp. 109-114.

[12] S. Whan Sung, J. Lee, and I.-B. Lee, PROCESS IDENTIFICATION AND PID CONTROLL. Singapore: John Wiley \& Sons, 2009.

[13] P. Ayu, "Pendeteksi dan Pelacakan Keberadaan Manusia Menggunakan Global Positioning System (GPS) Berbasis Android Melalui Google Maps Server," Politeknik Negeri Sriwijaya, 2014. 